\title{
Diagnosis of Aeromonas sobria and Saprolegnia sp. co-infection in rainbow trout fry (Oncorhynchus mykiss)
}

\author{
Remziye Eda YARDIMCID, Emre TURGAY ${ }^{(D)}$
}

Cite this article as:

Yardımc1, R.E., Turgay, E. (2021). Diagnosis of Aeromonas sobria and Saprolegnia sp. co-infection in rainbow trout fry (Oncorhynchus mykiss). Aquatic Research, 4(1), 65-72. https://doi.org/10.3153/AR21006

Istanbul University, Faculty of Aquatic Sciences, Department of Aquaculture and Fish Diseases, Istanbul, Turkey

ORCID IDs of the author(s): R.E.Y. 0000-0001-7737-8739 E.T. 0000-0001-9964-3919

Submitted: 16.06 .2020

Revision requested: 28.08 .2020

Last revision received: 27.10 .2020

Accepted: 30.10 .2020

Published online: 26.11 .2020

Correspondence:

Remziye Eda YARDIMCI

E-mail: etepecik@istanbul.edu.tr

\begin{abstract}
The aim of the study was to determine a considerable level of mortalities occurred in rainbow trout fry (Oncorhynchus mykiss) cultured in a research hatchery located in Marmara Region/Turkey. Totally 18 individuals (1-8 g) were investigated by using bacteriological and mycological methods. The affected fish showed skin darkening, prolapses and fungal mats at the base of the fins. According to morphological and biochemical characteristics of the isolates, all of them were identified as Aeromonas sobria. Saprolegnia sp. was also observed in squash preparations of the skin. All isolates were determined to be sensitive against florfenicol, enrofloxacin and ciprofloxacin. Histopathologically, vacuolar degeneration, haemorrhage and hyperaemia in the liver, tubular necrosis, periglomerular edema, and multifocal melanomacrophage deposits in the kidney and depletion of white pulp in the spleen were determined. Distal type epithelial cells hyperplasia was also observed in the gills. In diseased fish, motile Aeromonad septicaemia was described and Saprolegnia sp. was also detected in fins and skin lesions but it was considered to be a secondary infection.
\end{abstract}

Keywords: Rainbow trout fry, Oncorhynchus mykiss, Aeromonas sobria, Saprolegnia sp.

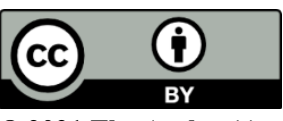

(C) 2021 The Author(s)

Available online at

http://aquatres.scientificwebjournals.com 


\section{Introduction}

Aquaculture activities have begun in Turkey in 1970s with rainbow trout (Oncorhynchus mykiss). Production of rainbow trout reached to $103.192 \mathrm{t}$ in 2018 in Turkey. In this period of time, by the increase of the number of fish farms and the production, disease problems has begun and until recently, these epizootics have increased rapidly parallel to the epizootics in other countries.

Motile Aeromonas septicaemia (MAS, Bacterial hemorrhagic septicemia, Aeromonad septicemia or Red Pest) caused by motile members of the genus Aeromonas is a ubiquitous disease affecting freshwater and marine fish all over the world. Fish pathogenic motile Aeromonads have often been associated with A. hydrophila (Austin and Austin, 2007). However, other members of the genus including $A$. sobria (Toranzo et al., 1989), A. allosaccharophila (Martinez-Murcia et al., 1992), A. caviae (Candan et al., 1995), A. jandaei (Esteve et al., 1995), A. veronii biovar sobria (Rahman et al., 2002) and A. schubertii (Alvarez et al., 2004) have also been detected as fish pathogens. These bacteria are known to cause various infections, especially gastroenteritis, by passing from animals to humans through food (Plumb and Hanson, 2011).

Aeromonas sobria has been recognized as a fish pathogen since 1987 and it was first reported in wild gizzard shad (Dorosoma cepedianum) in USA (Toranzo et al., 1989). In Turkey, A. sobria was first reported in intestinal tracts of healthy Atlantic salmons (Salmo salar) in Black Sea (Karatas, 1996). This pathogen was also detected in rainbow trout (Oncorhynchus mykiss) (Kayis et al., 2009; Ozer et al., 2009; Durmaz and Turk, 2009; Onuk et al., 2017), gold fish (Carassius auratus) (Korun and Toprak, 2007), green terror (Andinoacara rivulatus) (Şahin et al., 2019), gilthead sea bream (Sparus aurata) and sea bass (Dicentrarchus labrax) (Avsever et al., 2012) in Turkey. Wahli et al. (2005) declared that $A$. sobria is a causative agent of ulcerative skin diseases in farmed perch (Perca fluviatilis L.) with high mortality in Switzerland. A. sobria caused mass mortality of Garra rufa in a hatchery in Slovakia (Majtan et al., 2012).

Motile Aeromonas septicaemia are usually associated with stressors (Shoemaker et al., 2015). Poor feeding response, lethargy, pale gills, exophthalmia, and haemorhagic eyes are the most common clinical findings of MAS. Scale loss, frayed fins and necrotic lesions on the skin and friable organ are also observed (Toranzo et al., 1989; Karatas, 1996; Yardımcı and Aydın, 2011; Shoemaker et al., 2015).

Infection of eggs, fry and larger fish by water mould is another problem in cultured rainbow trout. Fungal infections can occur as a secondary infection alongside bacterial, viral or parasitic infections (Roberts, 2012). The present study aimed to determine the cause of mortalities in rainbow trout fry (Oncorhynchus mykiss) cultured in a research hatchery of Marmara Region in Turkey.

\section{Material and Methods}

\section{Bacteriological and Fungal Examination}

Totally 18 moribund individuals were investigated by using basic bacteriological and mycological methods. Samples were taken from internal organs and streaked onto Tryptic Soy Agar and Sabouraud \%2 Dextrose Agar and incubated at $22^{\circ} \mathrm{C}$ for $48-72 \mathrm{~h}$. After incubation, the isolated bacterial pure cultures were examined using standard protocols according to Austin and Austin (2007) and Buller (2004). Also rapid diagnosis kit API 20E was used in all isolates. Before necropsy, scrapings taken from fungal mats at the base of fins were stained with lacto-phenol cotton blue and examined under light microscope.

\section{Antimicrobial Susceptibility Testing}

All bacterial isolates were tested for antimicrobial susceptibility by using Kirby-Bauer disc diffusion method and performed using multidiscs (chloramphenicol, florfenicol, erythromycin, oxytetracycline, kanamycin, streptomycin, ampicillin, enrofloxacin, ciprofloxacin and flumequine). Isolates were streaked onto Mueller-Hinton agar (Oxoid), incubated at $22^{\circ} \mathrm{C}$ for $48 \mathrm{~h}$ and interpreted according to Clinical and Laboratory Standards Institute (CLSI) data (CLSI, 2013).

\section{Histological Examination}

Histopathological tissue samples from the internal organs were taken and fixed in $10 \%$ buffered formalin, processed with routine methods and embedded in paraffin blocks. Sections $(5 \mu \mathrm{m})$ were stained with haematoxylin-eosin (HE) (Culling, 1963) and examined under light microscope using the image analysis system NIS-Elements BR Microscope Imaging Software (Nikon Instruments).

\section{Results and Discussion}

The moribund fish samples externally showed loss of color or darkening of the skin (Figure 1A, B), eroded fins and fungal mats at the base of fins (Figure 1B), slight exophthalmia (Figure 1C) and prolapse (Figure 1D). Internally, pale liver and visceral fat and accumulation of a mucoid yellowish fluid in the intestines were observed (Figure 1E). Petechial haemorrhage in the liver and splenomegaly were detected in a few sample (Figure 1F). These clinical findings are similar to the typical MAS findings reported by many researchers (Snieszko and Bullock, 1965; Toranzo et al., 1989; Karatas, 
1996; Yardımcı and Aydın, 2011; Shoemaker et al., 2015). In MAS, outbreaks are associated with poor management and environmental status and this stress-related situation causes mortality (Plumb and Hanson, 2011). In this study, a considerable level of mortalities occurred in the hatchery fish stocks.

Total of twenty Gram-negative motile isolates were recovered from kidney, spleen, liver and blood of ten moribund fish samples. These motile Gram-negative short rods produced white-cream convex colonies on Tryptic Soy Agar at $22^{\circ} \mathrm{C}$ after $48 \mathrm{~h}$. All isolates showed the same biochemical, morphological characteristics and API 20E results. The bacterium produces arginine dihydrolase, catalase, $\beta$-galactosidase, indole, lysine decarboxylase and oxidase but does not hydrolyse esculin. The API 20E profile is so similar with previous A. hydrophila reports (Buller, 2004; Austin and Austin, 2007). They were characterized by haemolytic colonies on sheep blood agar when grown at $25^{\circ} \mathrm{C}$ and $30^{\circ} \mathrm{C}$ and all of them were identified as Aeromonas sobria (Table 1).

Table 1. Some phenotypic and morphological characteristics of Aeromonas sobria isolates

\begin{tabular}{|l|c|}
\hline Characteristics & A. sobria $\mathrm{n}=20$ \\
\hline Colony colour & Cream \\
\hline Morphology & Rods \\
\hline Gram Staining & + \\
\hline Motility & + \\
\hline Cytochrome Oxidase & + \\
\hline Catalase & + - \\
\hline O/F Test & - \\
\hline Inositol & - \\
\hline Arabinose & - \\
\hline Sorbitol & - \\
\hline Esculin & - \\
\hline Production of $\mathrm{H}_{2} \mathrm{~S}$ & + \\
\hline Citrate & + \\
\hline ONPG & $\mathrm{R}$ \\
\hline $0 / 129(150 \mu \mathrm{g})$ & + \\
\hline Indole & $\mathrm{V}$ \\
\hline Methyl Red & + \\
\hline Voges-Proskauer Test & + \\
\hline Arginine & - \\
\hline Lysine & - \\
\hline Ornithine & 724713757 \\
\hline API 20E results & \\
\hline
\end{tabular}

+: positive reaction, -: negative reaction, $\mathrm{R}$ : resistant, $\mathrm{V}$ : variable
Oomycetes of the genus Saprolegnia, especially $S$. parasit$i c a$, are economically important pathogens of fish. Saprolegnia species also affect to decline of the amphibians and crustaceans. In Japan, S. parasitica and S. diclina caused high mortality of cultured rainbow, coho salmon (Oncorhynchus kisutch) and ayu (Plecoglossus altivelis) (Yuasa et al., 1977; Yuasa and Hatai, 1995). Grey-white patches on fish skin having cotton-like appearance underwater were also observed in some rainbow trout fries. When fungal mats that stained with lacto-phenol cotton blue were examined under light microscope, Saprolegnia sp. observed in fins and skin lesions. No growth was detected on Sabouraud \%2 Dextrose Agar after the incubation at $22^{\circ} \mathrm{C}$ after $72 \mathrm{~h}$. For this reason, Saprolegnia infection was considered as a secondary, opportunistic infection.

Durmaz and Türk (2009) reported that Aeromonas sobria isolates were highly resistant to oxytetracycline, streptomycin and carbenicillin in their study. Onuk et. al (2017) reported that $A$. sobria strains, that were isolated from rainbow trout, from mullet and in water resources from different geographic regions of Turkey, were gentamicin-sensitive but resistant to beta-lactam antibiotics and ampicillin. In this study, all isolates were found to be susceptible to florfenicol, enrofloxacin and ciprofloxacin, while they were semi-sensitive to chloramphenicol and flumequin, and resistant to erythromycin, oxytetracycline, kanamycin, streptomycin, ampicillin and vibriostatic agent $\mathrm{O} / 129$. Similar sensitivity to ciprofloxacin and enrofloxacin were reported by other researchers (Guz and Kozinska, 2004; Durmaz and Turk, 2009; Onuk et al., 2017; Şahin et al., 2019). We found that the highest resistance was against ampicillin and oxytetracycline. While ampicillin is used for the treatment of human diseases, oxytetracycline is used in the treatment of bacterial diseases in freshwater fish farming in Turkey. The possible cause of resistance to these antibiotics is thought to be due to the heavy use of these antibiotics.

Histopathologically, vacuolar degeneration and necrosis in the parenchyma cells of liver, hyperaemia and haemorrhage in the liver (Figure 2A, B), depletion of the spleen (Figure 2C), myopathy (Figure 2D), tubular necrosis, periglomerular edema and multifocal melanomacrophage centers in the kidney (Figure 2E), hyperplasia of gill lamellae and disruption of gill epithelium (Figure 2F) and depletion of white pulp in the spleen were determined. Our histopathological results are similar with previously reported histopathological findings of Motile Aeromonad infections (Yardimc1 and Aydin, 2011; Laith and Najiah 2013; Saharia et al., 2018). 


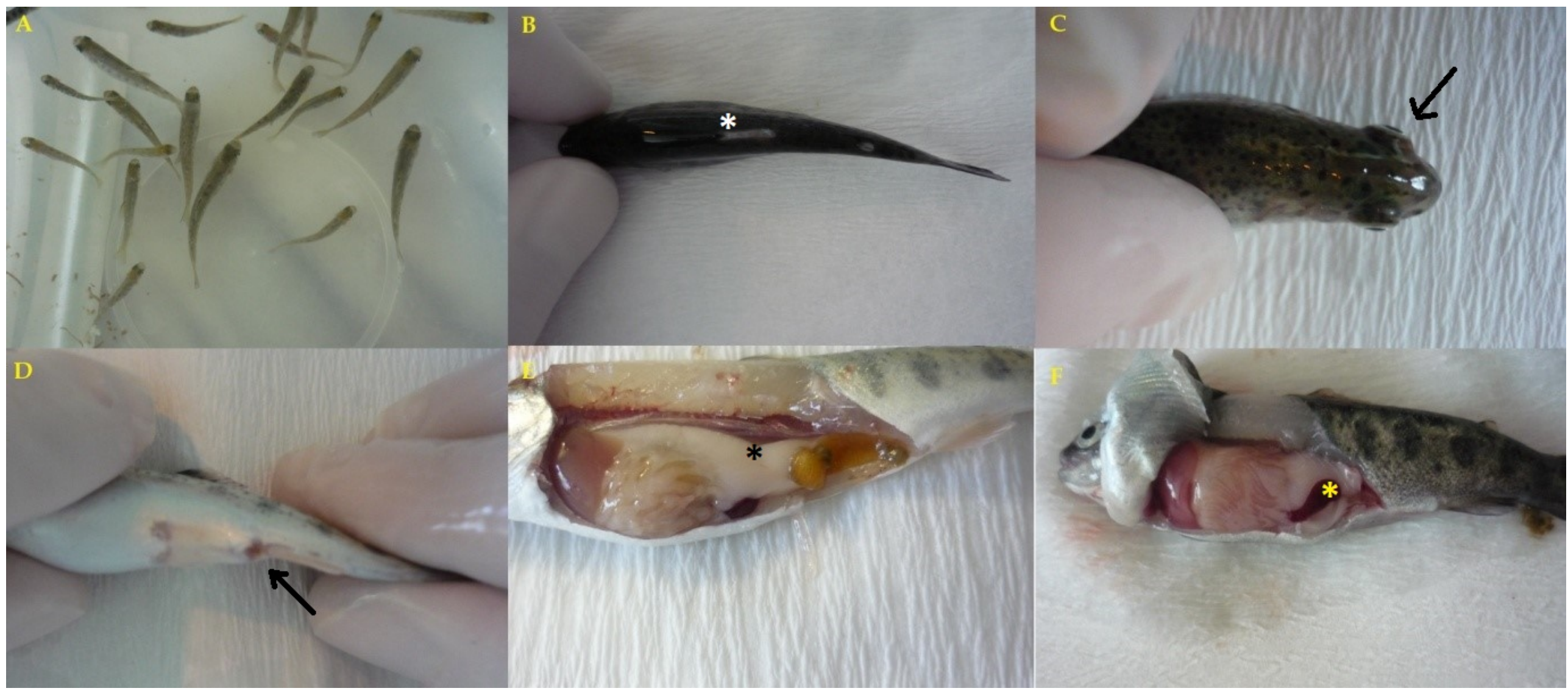

Figure 1. Moribund fish showed (A) depigmentation of the skin, (B) eroded fins and fungal mats at the base of fins (*), (C) slight exophthalmia (arrowed), (D) haemorrhage and prolapse (arrowed), (E) visceral fat $(*)$ and (F) splenomegaly $(*)$. 


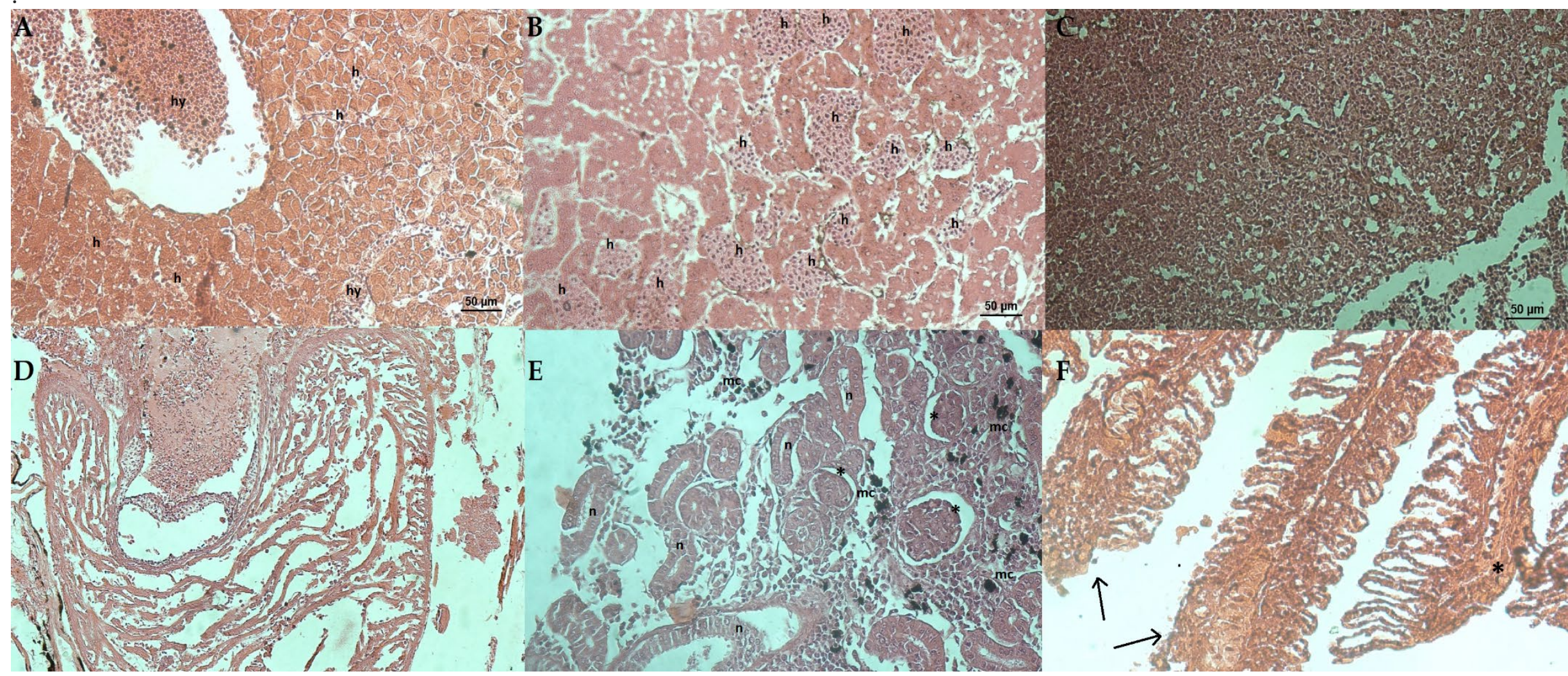

Figure 2. Photomicrographs of the tissue sections of moribund rainbow trout fries. (A) Vacuolar degeneration and necrosis in the parenchyma cells of liver, hyperaemia and haemorrhage in the liver H\&E X20, (B) necrosis in the parenchyma cells of liver and haemorrhage H\&E X20, (C) depletion of white pulp in the spleen H\&E X20, (D) myopathy H\&E X10, (E) tubular necrosis (n), periglomerular edema $(*)$ and multifocal melanomacrophage centers $(\mathrm{mc})$ in the kidney H\&E X20, (F) hyperplasia of the gill lamellae (arrowed) and disruption of the gill epithelium (*) H\&E X20. 
A co-infection caused by Saprolegnia parasitica and Aeromonas hydrophila were described previously in sea bass by Dinçtürk et al. (2018) in a recirculating aquaculture system and they suggested that $S$. parasitica could be dominant in the outbreak, but in our case we found that Aeromonas sobria was the primary cause.

\section{Conclusion}

In aquaculture, increased production, pressures on faster growth, high stock density could create conditions conducive to outbreak of bacterial infectious diseases. In conclusion, motile Aeromonad septicaemia was described in this study. Saprophytic fungus Saprolegnia sp. played a role as a secondary pathogen in this infection. In addition, according to the data obtained from this study, enrofloxacin was successful with a feed dose of $20 \mathrm{~g} / 10 \mathrm{~kg} / 7-8$ days in the treatment of diseased fish.

\section{Compliance with Ethical Standard}

Conflict of interests: The authors declare that for this article they have no actual, potential or perceived conflict of interests.

Ethics committee approval: This study was approved by Istanbul University Local Committee on Animal Research Ethics (Decision year 2013/ number 70) and conducted in accordance with ethics committee procedures of animal examination.

Funding disclosure: This work was supported by the Scientific Research Projects Coordination Unit of Istanbul University Project number: 35964

Acknowledgments: We thank Prof. Dr. Süheyla KARATAŞ for her comments.

\section{Disclosure: -}

\section{References}

Alvarez, R.J.D., Agurto, C.P., Alvarez, A.M., Obregon, J. (2004). Resistencia Antimicrobiana en Bacterias Aisladas de Tilapias, Agua y Sedimento en Venezuela. Revista Cientifica, FCV-LUZ, 19(6), 491-499.

Avsever, M.L., Onuk, E.E., Turk, N., Tunaligil, S., Eskiizmirliler, S., Incoglu, S., Yabanli, M. (2012). Pasteurellosis cases in sea bass and sea bream cultured in the Aegean region and other bacteria isolated from these cases. Bornova Veteriner Kontrol ve Arastırma Enstitüsü Dergisi, 34(48), 9-16.

Austin, B., Austin, D. (2007). Bacterial Fish Pathogens Disease of Farmed And Wild Fish. $7^{\text {th }}$ (revised) Edition, Springer-Praxis Publishing, Chichester.
Buller, N.B. (2004). Bacteria from Fish and Other Aquatic Animals: A Practical Identification Manuel. CABI Publishing, Cambridge USA, ISBN 0851997384.

https://doi.org/10.1079/9780851997384.0000

Candan, A., Kucuker, M.A., Karatas, S. (1995). Motile aeromonad septicaemia in Salmo salar cultured in the Black Sea in Turkey. Bulletin of the European Association of Fish Pathologists, 15(6), 195-196.

CLSI, (2013). Performance Standards for Antimicrobial Susceptibility 23th informational supplement. CLSI Document M100- S23, (ISBN1-56238-865-7-Print:1-56238-866-5Electronic) Clinical and Laboratory Standards Institute, 950 West Valley Road, Suite 2500, Wayne, Pennsylvania, 19087 USA.

Culling, C.F.A. (1963). Handbook of Histopathological Techniques. Second edition, Butterworth \& Co.

Dinçtürk, E., Tanrıkul, T.T., Türk Çulha, S. (2018). Fungal and Bacterial Co-Infection of Sea Bass (Dicentrarchus labrax, Linnaeus 1758) in a Recirculating Aquaculture System: Saprolegnia parasitica and Aeromonas hydrophila. Aquatic Sciences and Engineering, 33(3), 67-71. https://doi.org/10.26650/ASE201811

Durmaz, Y., Türk, N. (2009). Alabalık işletmelerinden motil aeromonasların izolasyonu ve antibiyotiklere duyarlılıklarının saptanması. Kafkas Üniversitesi Veteriner Fakültesi Dergisi, 15 (3): 357-361.

Esteve, C., Amaro C., Garay, E., Santos, I., Toranzo, A.E. (1995). Pathogenicity of live bacteria and extracellular products of motile Aeromonas isolated from eels. Journal of Applied Microbiology, 78(5), 555-562.

https://doi.org/10.1111/j.1365-2672.1995.tb03099.x

Guz, L., Kozinska, A. (2004). Antibiotic susceptibility of Aeromonas hydrophila and A. sobria isolated from farmed carp (Cyprinus carpio L). Bulletin of the Veterinary Institute in Pulawy, 48, 391-395.

Karataş, S. (1996). Salmo salar L larda bağırsak florasından Aeromonas cinsi bakterilerin izolasyonu. MSc Thesis, Istanbul University.

Kayis, S., Capkin, E., Fikri, B., Altinok, I. (2009). Bacteria in rainbow trout (Oncorhynchus mykiss) in the Southern Black Sea Region of Turkey - a survey. Israeli Journal of Aquaculture-Bamidgeh, 61(4), 339-344. 
Korun, J., Toprak, B.H. (2007). Japon (Carassius auratus) balıklarından izole ve identifiye edilen Aeromonas hydrophila, A. caviae ve A. sobria türlerinin antibiyotik hassasiyetleri, hemolitik aktiviteleri ve siderofor üretimleri üzerine bir çalışma. Türk Sucul Yasam Dergisi, 3(5), 776-782.

Laith, A.R., Najiah, M. (2013). Aeromonas hydrophila: antimicrobial susceptibility and histopathology of isolates from diseased catfish, Clarias gariepinus (Burchell). Journal of Aquaculture Research \& Development, 5(2), 1-7.

Majtan, J., Cerny, J., Ofukana, A., Takac, P., Kozanek, M. (2012). Mortality of therapeutic fish Garra rufa caused by Aeromonas sobria. Asian Pacific Journal of Tropical Biomedicine, 2(2), 85-7.

https://doi.org/10.1016/S2221-1691(11)60197-4

Martinez-Murcia, A.J., Esteve, C., Garay, E., Collins, M.D. (1992). Aeromonas allosaccharophila sp. nov., a new mesophilic member of the genus Aeromonas. FEMS Microbiology Letters, 91, 199-205.

https://doi.org/10.1111/j.1574-6968.1992.tb05209.x

Onuk, E.E., Çaycı Tanrıverdi, Y., Çoban, A.Y., Çiftçi, A., Balta, F., Didinen, B.I., Altın, S. (2017). Balık ve yetiştirme suyu kökenli Aeromonas izolatlarının antimikrobiyal duyarlılıklarının saptanması. Ankara Üniversitesi Veteriner Fakültesi Dergisi, 64, 69-73.

https://doi.org/10.1501/Vetfak_0000002777

Ozer, S., Bulduklu, P., Tezcan, S., Dönmez, E., Aydin, E., Aslan, G., Emekdas, G. (2009). Genetic diversity and antimicrobial susceptibility of motile aeromonads isolated from rainbow trout (Oncorhynchus mykiss, walbaum) farms. Journal of Applied Ichthyology, 25 (2), 195-200.

https://doi.org/10.1111/j.1439-0426.2008.01222.x

Plumb, J.A., Hanson, L.A. (2011). Health Maintenance and Principal Microbial Diseases of Cultured Fishes. 3rd edn. Ames, IA: Wiley-Blackwell, 492 pp.

Rahman, M., Colque-Navarro, P., Kühn, I., Huys, G., Swings, J., Möllby, R. (2002). Identification and Characterization of Pathogenic Aeromonas veronii Biovar Sobria Associated with Epizootic Ulcerative Syndrome in Fish in Bangladesh. Applied and Enviromental Microbiology, 68(2), 650-655.

https://doi.org/10.1128/AEM.68.2.650-655.2002
Roberts, R.J. (2012). Fish Pathology. 4.Edition. Blackwell Publishing, United Kingdom, pp.387-390 ISBN: 978-1-11822296-6

https://doi.org/10.1002/9781118222942

Saharia, P., Pokhrel, H., Kalita, B., Hussain, I.A., Islam, S.(2018). Histopathological changes in Indian Major Carp, Labeo rohita (Hamilton), experimentally infected with Aeromonas hydrophila associated with hemorrhagic septicemia of Central Brahmaputra valley of Assam, India. Journal of Entomology and Zoology Studies, 6(5), 06-11

Shoemaker, C., Xu, D., Lafrentz, B., Lapatra, S. (2015). Overview of Fish Immune System and Infectious Diseases. P1-24, In: Dietary Nutrients, Additives, and Fish Health (Ed: Cheng-Sheng Lee, Chhorn Lim, Delbert M. Gatlin II, and Carl D. Webster). Published by JohnWiley \& Sons, Inc., Hoboken, New Jersey384p. ISBN: 10987654321.

https://doi.org/10.1002/9781119005568.ch1

Snieszko, S.F., Bullock, G.L., (1965). Freshwater fish diseases caused by bacteria belonging to the genera aeromonas and pseudomonas. U.S.A. Fish and wildlife service. Fishery Icaflet No.459.

Şahin, A.G., San, A.T., Gürçay, S., Alkan, S.M. (2019). Determination of antibiotic resistance sensitivity of Aeromonas sobria isolated from Green terror (Andinoacara rivulatus). Ege Journal of Fisheries and Aquatic Sciences, 36(3), 265-269.

https://doi.org/10.12714/egejfas.2019.36.3.07

Toranzo, A.E., Baya, A.M., Romalde, J.J. Hetrick, F.M. (1989). Association of Aeromonas sobria with mortalities of adult gizzard shad, Dorosoma cepedianum lesueur. Journal of Fish Diseases, 12, 439-448.

https://doi.org/10.1111/j.1365-2761.1989.tb00555.x

TUIK (2019). http://www.tuik.gov.tr/PreHaberBulten-

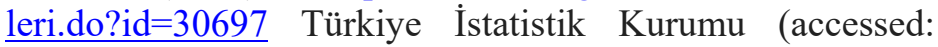
12.06.2019).

Wahli, T., Burr, S.E., Pugovkin, D., Mueller, O., Frey, J. (2005). Aeromonas sobria, a causative agent of disease in farmed perch, Perca fluviatilis L.. Journal of Fish Diseases, 28(3), 141-150.

https://doi.org/10.1111/j.1365-2761.2005.00608.x

Yardımcı, B., Aydın, Y. (2011). Pathological findings of experimental Aeromonas hydrophila infection in Nile tilapia 
(Oreochromis niloticus). Ankara Üniversitesi Veteriner Fakültesi Dergisi, 58, 47-54.

https://doi.org/10.1501/Vetfak_0000002448

Yuasa, K, Hatai, K, (1995). Relationship between pathogenity of Saprolegnia spp. Isolates to rainbow trout and their biological characteristics. Fish Pathology, 30, 101-106.

https://doi.org/10.3147/jsfp.30.101
Yuasa, K, Kitancharoen, N., Hatai, K. (1977). Simple method to distinguish between Saprolegnia parasitica and $S$. diclina isolated from fishes with saprolegniasis. Fish Pathology, 32, 175-176.

https://doi.org/10.3147/jsfp.32.175 